\title{
Genome-Shuffling-Improved Acid Tolerance and Lactic Acid Production in Lactobacillus plantarum for Commercialization
}

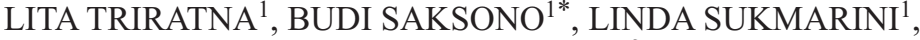 \\ AND ASEP SUPARMAN ${ }^{2}$ \\ ${ }^{1}$ Research Center for Biotechnology, Lembaga Ilmu Pengetahuan Indonesia, Jalan Raya Bogor Km 46, \\ Cibinong 16911, Indonesia; ${ }^{2}$ Department of Food Science and Technology, Institut Pertanian Bogor, \\ Darmaga Campus, Bogor 16680, Indonesia
}

\begin{abstract}
We applied genome shuffling to improve the acid tolerance of Lactobacillus plantarum, while simultaneously enhancing lactic acid production. The starting populations were mutant libraries generated by gradual low $\mathrm{pH}$ adaptation and ultraviolet irradiation and then which were subjected to recursive protoplast fusion. A library of shuffled mutants (fusants) with genetic exchange is achieved by repetition of this process. After three rounds of genome shuffling, we obtained the best performing fusant that grow better at low $\mathrm{pH} 4.0$ and consume glucose faster than does the wild type. In addition, lactic acid production of this fusant was $64 \%$ higher than that of the wild type. These results demonstrated that the genome shuffling has been successful in engineering L. plantarum with multiple beneficial improved phenotypes. In the future, this technology is a promising candidate to accelerate poorly characterized strains for commercialization.
\end{abstract}

Key words: genome shuffling, Lactobacillus plantarum, lactic acid, acid tolerance

Teknik genome shuffling telah diaplikasikan untuk memperbaiki toleransi asam Lactobacillus plantarum dan secara simultan meningkatkan produksi asam laktatnya. Populasi awal yang digunakan ialah pustaka mutan yang didapat dengan menurunkan $\mathrm{pH}$ medium pertumbuhan secara bertahap dan iradiasi sinar ultra violet. Pustaka mutan kemudian digunakan dalam proses fusi protoplas secara berulang. Hasil shuffling dari pustaka mutan disebut fusan. Paska pengulangan yang ke-3 dari genome shuffling didapatkan fusan unggul yang mampu tumbuh dengan baik pada $\mathrm{pH} 4.0$ dan mengonsumsi gula lebih cepat dibandingkan dengan galur liar. Produksi asam laktat oleh fusan ini meningkat $64 \%$ dibandingkan dengan galur liar. Hasil ini menunjukkan bahwa teknik genome shuffling telah berhasil merekayasa L. plantarum yang memiliki keunggulan fenotipe. Di masa mendatang teknik ini mampu menjadi kandidat yang menjanjikan dalam komersialisasi galur mikrob yang belum dikarakaterisasi dengan baik.

Kata kunci: genome shuffling, Lactobacillus plantarum, asam laktat, toleransi asam

Lactic acid has been widely used in the food, pharmaceutical and cosmetics industries. It has recently emerged as an important source for the production of other chemicals, particularly polylactic acid for biodegradable plastic (Singh et al. 2006). Most lactic acid is manufactured by fermentation process as opposed to chemical synthesis since it is environmentally friendly (John et al. 2009). Fermentation at low $\mathrm{pH}$ contributes to the economics of the lactic acid purification process. Thus, the commercial goal of improving the growth and lactic acid production of microorganisms at acid condition could decrease waste and reduce the cost of production. Moreover, it also reduces potential contamination (Porro et al. 1999; Carlson and Peters 2002; Singh et al. 2006).

L. plantarum is of commercial interest for lactic acid production, but the effect of acid stress on the bacterium is a complex and poorly understood process. As a result, it is difficult to improve lactic acid production with rational engineering or direct genetic manipulation. On the other hand, classical strainimprovement-methods have succeeded in obtaining

*Corresponding author: Phone: $+62-21-8754587$, Fax:+62-21-8754588, E-mail: saksonobudi@yahoo.com many industrial strains, but this is a time-consuming and laborious process because of many repeated rounds of random mutation and selection methods, especially for engineering complex phenotypes (Zhang et al. 2002). Thus, an efficient technology named genome shuffling has been presented as a novel whole-genome engineering approach for the rapid improvement of cellular phenotypes. This approach uses recursive protoplast recombination throughout the entire genome without the necessity for genome sequence data or network information (Patnaik et al. 2002; Stephanopoulos 2002). At present, genome shuffling has been successfully applied for the improvement acid tolerance in Lactobacillus (Patnaik et al. 2002), acid and glucose tolerance in L. rhamnosus (Wang et al. 2007; Yu et al. 2008), degradation of pentachlorophenol in Sphingobium chlorophenolicum (Dai and Copley 2004) and the production of hydroxycitric acid in Streptomyces (Hida et al. 2007). However, shuffling of an industrial strain L. plantarum has not been reported.

Thus, in the present study, we applied genome shuffling to improve the acid tolerance of $L$. plantarum while simultaneously enhancing lactic acid production. 


\section{MATERIALS AND METHODS}

Bacterial Strains and Media. Lactobacillus plantarum was obtained from Biotechnology Type Culture Collection (BTCC) Research Center for Biotechnology-LIPI, Indonesia. The strain was stored in a deMan Rogosa and Sharpe (MRS) broth with 10\% $\left(\mathrm{w} \mathrm{v}^{-1}\right)$ glycerol at $-70{ }^{\circ} \mathrm{C}$. The strain was grown in MRS broth from a $1 \%$ inoculum with $18 \mathrm{~h}$ incubation at $37{ }^{\circ} \mathrm{C}$. At least two generations of precultures were required just before the experiments.

Yeast extract fermentation medium (YE) contained $100 \mathrm{~g} \mathrm{~L}^{-1}$ glucose and $15 \mathrm{~g} \mathrm{~L}^{-1}$ yeast extract. Regeneration medium (RM) was MRS agar without Tween 80 and supplemented with $0.5 \% \mathrm{BSA}, 25 \mathrm{mM} \mathrm{MgCl}, 25 \mathrm{mM}$ $\mathrm{NaCl}_{2}$, and $0.5 \mathrm{M}$ sucrose (Patnaik et al. 2002).

Adaptation of $L$. plantarum to Low pH. Culture adaptation was achieved by modification of the procedure from Patnaik et al. (2002), through a continuous and controlled decrease in broth medium $\mathrm{pH} 6.2$ to $\mathrm{pH} 5.0$ and $\mathrm{pH}$ 4.0. For scenarios in which the imposed $\mathrm{pH}$ was not tolerated, and the culture steady-state could not be maintained, the culture was replaced with fresh MRS broth of $\mathrm{pH}$ lower than 4.0. Adapted wild-type strain in $\mathrm{pH} 4.0$ medium was then used as the parental, or starter, for genome shuffling.

Strain Mutagenesis and Mutant Screening. The cells of L. plantarum wild-type strain were grown in a $10 \mathrm{ml}$ MRS broth at $37^{\circ} \mathrm{C}$ for $18 \mathrm{~h}$. Cultures were centrifuged at $4500 \times \mathrm{g}$ for $10 \mathrm{~min}$. UV irradiation was performed by exposing samples of the wild-type strain in uncovered petri dish directly to UV light at a distance $20 \mathrm{~cm}$ with $120 \mathrm{~mJ} \mathrm{~cm}$ of intensity for $30 \mathrm{~s}$ using UV Crosslinker (Hoefer UVC500, USA). The mutants were then spread on MRS agar plates containing $2 \%\left(\mathrm{w} \mathrm{v}^{-1}\right) \mathrm{CaCO}_{3}$ and incubated at $37^{\circ} \mathrm{C}$ for $48 \mathrm{~h}$. The fast growing colonies, which had bigger transparent haloes compared to colony diameter, were picked off and selected as the starter for the genome shuffling.

Protoplast Preparation and Genome Shuffling. Protoplast formation was carried out as described by Cocconcelli et al. (1986) with modification. Strains were cultured at $37^{\circ} \mathrm{C}$ for $18 \mathrm{~h}$ in MRS broth. The cells were harvested by centrifugation at $4500 \times \mathrm{g}$ and $4{ }^{\circ} \mathrm{C}$ for $10 \mathrm{~min}$, and washed twice with distilled water. The cells from a $5 \mathrm{~mL}$ culture were suspended in Lactobacillus protoplast buffer (LPB) $(50 \mu \mathrm{L}$ Tris $\mathrm{HCl} 1 \mathrm{M} \mathrm{pH}$ 6.3, $2.5 \mathrm{~mL}$ sucrose $1 \mathrm{M}, 2 \mathrm{~mL} \mathrm{CaCl}_{2} 50$ $\mathrm{mM}$, and $450 \mu \mathrm{L}$ distilled water) containing lysozyme $\left(2.0 \times 10^{5} \mathrm{U} \mathrm{mL}^{-1}\right)$ and incubated at $37^{\circ} \mathrm{C}$ for $2 \mathrm{~h}$ for protoplast formation.
The starting populations for genome shuffling were mutants-library-generated by gradually low $\mathrm{pH}$ adaptation and ultraviolet (UV) irradiation. Fusions between protoplast preparations were generated by mixing an approximately equal number of protoplasts from two populations as described by Patnaik with slightly modification (Patnaik et al. 2002). The shuffled mutants, named fusants were then cultivated in regeneration medium. Each culture was incubated at $37^{\circ} \mathrm{C}$ for $6 \mathrm{~h}$ and processing continued by spreading in selection medium of MRS agar plates containing $2 \%\left(\mathrm{wv}^{-1}\right) \mathrm{CaCO}_{3}, \mathrm{pH} 4.0$, and then incubated at $37{ }^{\circ} \mathrm{C}$ for 3-4 d. Subsequent colonies were selected randomly to carry out further selection with small-scale fermentation analysis in $2 \mathrm{~mL}$ YE broth culture at $\mathrm{pH}$ 4.0. The cultures were incubated at $37{ }^{\circ} \mathrm{C}$ for $48 \mathrm{~h}$. Profiles of both growth and lactic acid production for each culture were then followed. The value of both growth and lactic acid production then were analyzed using SPSS program to identify the fusants that have a significant change in their growth and lactic acid production compared to that of control.

The formation of protoplasts, their fusion, and subsequent regeneration was repeated three times with the pooled regenerated cells from one fusion being the inoculum for the subsequent protoplast culture. Samples from each of the pooled fusion libraries F1-F3 (first/F1, second/F2, third/F3) were saved for later analysis. Non-shuffled (unshuffled) controls were prepared by the recursive formation and regeneration of protoplast without exposure to PEG.

Shaking Flask Analysis. The best performing selected shuffled strain, F3-33, after three rounds of genome shuffling (F3) was cultured in $10 \mathrm{~mL}$ MRS broth before being transferred into $100 \mathrm{~mL}$ YE medium at $\mathrm{pH} 4.0$ in shaking flasks $(250 \mathrm{~mL})$ at $100 \mathrm{rpm}, 37^{\circ} \mathrm{C}$. The growth, $\mathrm{pH}$, residual glucose, and lactic acid production were periodically monitored up to $96 \mathrm{~h}$.

Analytical Methods. Cell growth was monitored by measuring cell number via the optical density at $600 \mathrm{~nm}\left(\mathrm{~A}_{600 \mathrm{~mm}}\right)$. Supernatants of the samples for assay were collected by centrifugation. Total lactic acid for fusant selection was estimated according to the titration method, and the total sugar concentration was determined using the phenol-sulphuric acid method, as described by Dubois et al. (1956). Furthermore, total lactic acid of the selected F3 fusant was then determined by reversed-phase highperformance liquid chromatography (HPLC) (Shimadzu LC-6AD, Japan) using a C18 silica column (HPLC Packed Column UG120 Shiseido, Japan) with $\mathrm{UV}$ detector set at $220 \mathrm{~nm}$. The column was eluted with $20 \mathrm{mM} \mathrm{NaH}_{2} \mathrm{PO}_{4}(\mathrm{pH} 2.55)$ as a mobile phase at a flow 
rate of $1.0 \mathrm{~mL} \mathrm{~min}{ }^{-1}$. All of the measurements were performed in duplicate from two independent experiments.

\section{RESULTS}

Isolation of Initial Strains. The first population of the adapted acid-mutant-library was achieved by slowly decreasing the $\mathrm{pH}$ from 6.2 to 4.0 over a period of $840 \mathrm{~h}$. A stable population of L. plantarum was able to grow at $\mathrm{pH} 4.0, \mathrm{a} \mathrm{pH}$ that severely inhibits growth of the wild-type strain. The second population was enriched for acid tolerance of the wild-type strain using UV mutant library selected on MRS-agar-plates at $\mathrm{pH}$ 4.0. Ten colonies which had bigger transparent haloes compared to colony diameter were obtained (unpublished data).

Genome Shuffling. The resulting new population (shuffled strains/fusants) represented a larger combinatorial library of the original genetic diversity. After the first fusion, 56 colonies were picked off randomly for further selection in small-scale fermentation. Selection was done by SPSS program based on their growth and lactic acid production values. Fusants with higher and lower lactic acid production respectively were shown (Fig 1, 2, 3). First-round shuffling also resulted 29 fusants with growth-faster compared to that of wild-type (unpublished data). Among those fusants, 4 fusants, i.e. F1-2, F1-16, F1-48, and F1-50, showed the value of relative lactic acid production per $\mathrm{A}_{600 \mathrm{~nm}}$ higher than 1.0 (control) and 2 fusants, i.e., F1-6 and F1-30 showed relative growth-fastest (120\%). Relative lactic acid production is the value of total lactic acid produced by sample divided by total lactic acid produced by control, whereas relative growth is the value of cell density of sample divided by that of control at $\mathrm{A}_{600 \mathrm{~nm}}$. Two fusants from the selected F1 fusants library, with higher relative lactic acid production/ $\mathrm{A}_{600 \mathrm{~nm}}(\mathrm{p}<0.05)$ to that of wild type, F1-30 and F1-16 (shown as red bar) were used as resources for the next fusion (Fig 1a). Figure $1 \mathrm{~b}$ showed 4 fusants (F2-3, F2-22, F2-26, and F2-65) and 10 fusants (F2-64, F2-77, F2-78, F2-79, F2-88, F2-89, F2-90, F2-91, F2-109 and F2-116) with lower and higher lactic acid production, respectively. Second round of shuffling also resulted 87 of fusants with growth faster compared to that of F1-30 as control (unpublished data). Among second shuffled library F2, 4 fusants, namely F2-78, F2-88, F2-89, and F2-91 were selected and used for the next fusion (Fig 1c). These fusants were selected due to their higher relative lactic acid production to that of F1-30 as control ( $\mathrm{p}<0.05)$. The result showed 4 fusants (F3-33, F3-118, F3-119, and F3-176) and 34 fusants with higher and lower
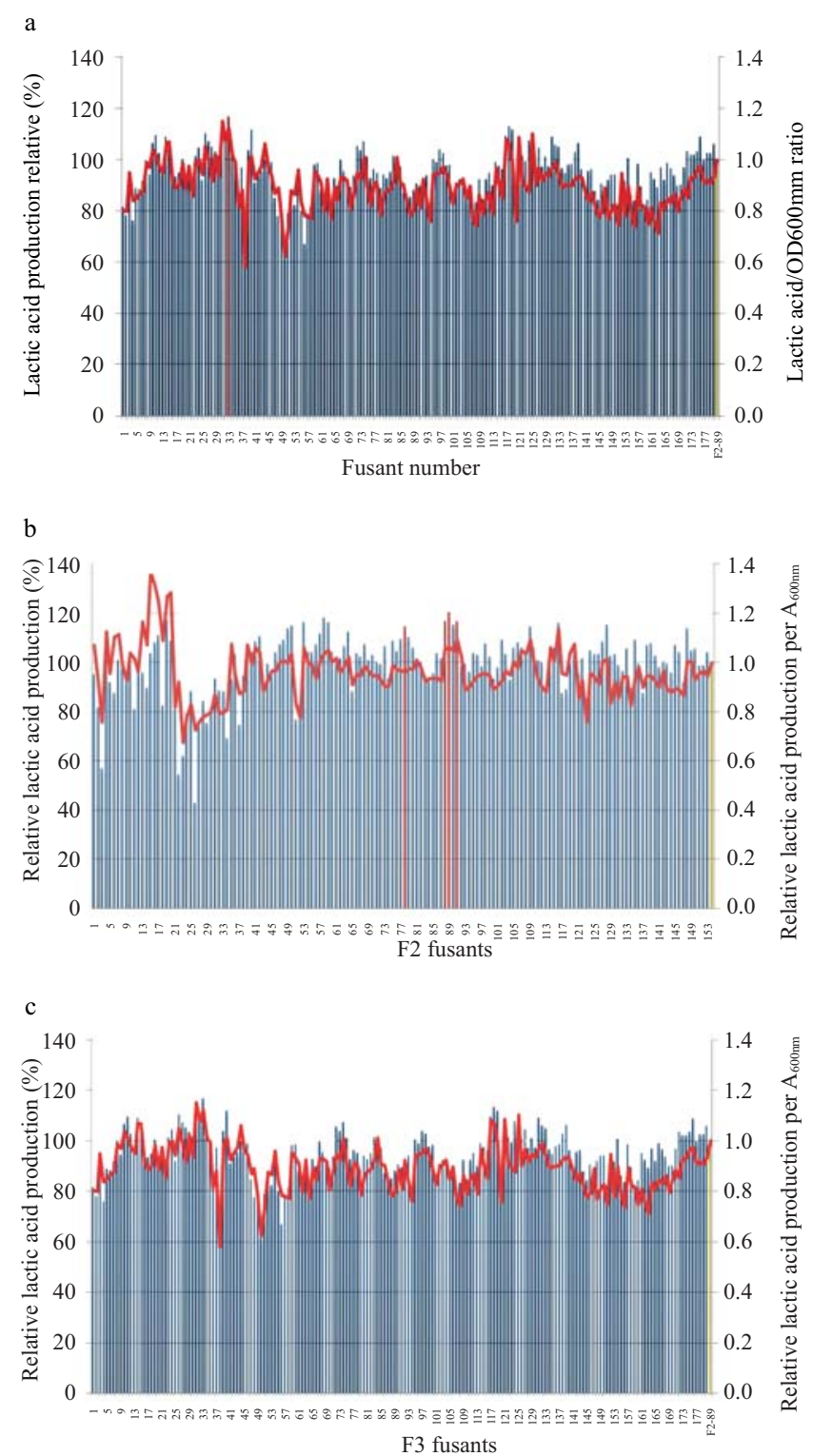

Fig 1 Relative lactic acid production to the control and relative lactic acid production per $\mathrm{A}_{600 \mathrm{~nm}}$. a, F1 fusants library; b, F2 fusants library; c, F3 fusants library Lactobacillus plantarum. Wild-type strain (WT), F130 fusant, and F2-89 fusant is used as the control for F1, F2, and F3fusants library respectively (For more detail information see result session of genome shuffling). X-ordinate represents colonies numbers from each fusant library. Bar represents relative lactic acid production of fusants, line represents relative lactic acid production per $\mathrm{A}_{600 \mathrm{~mm}}$. Red bar indicated the fusants were choose for next rounds. $\longrightarrow$, laktat; $=$, yield.

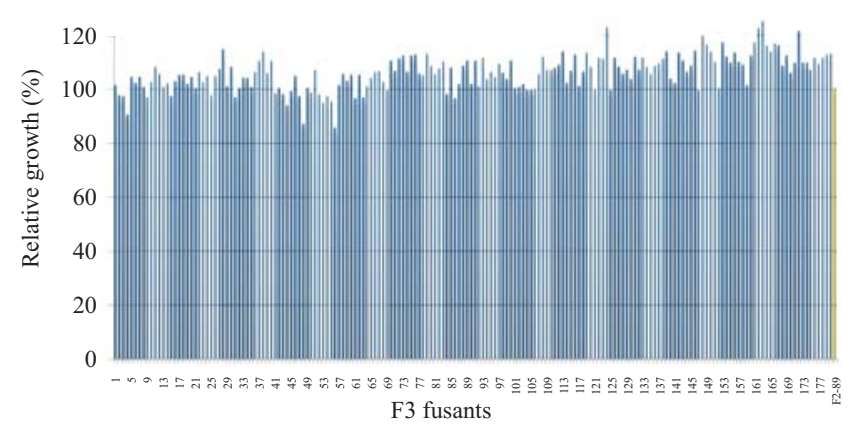

Fig 2 Relative growth of F3 Lactobacillus plantarum fusants library to F2-89 fusant as a control. X-ordinate represents colonies numbers from $\mathrm{F} 3$ fusants library. 


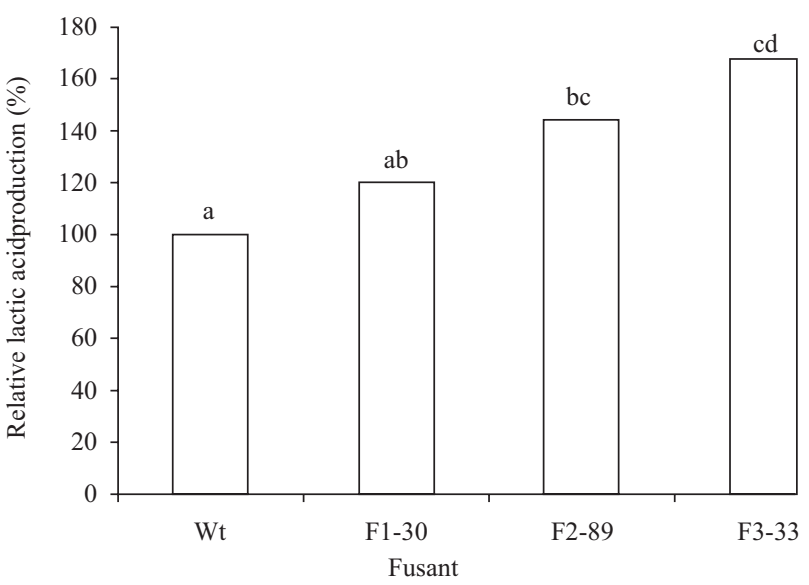

Fig 3 Relative lactic acid production of the best performing fusants from each of three rounds of genome shuffling (F1-F3) to the wild type; wt is wild type strain of Lactobacillus plantarum. F1-30 is fusant from colony number 30 of first fusion round, F2-89 is fusant from colony number 89 of second fusion round, while F3-33 is fusant from colony number 33 of third fusion round. Bar with different letters are significantly different by Dunnet test at $\mathrm{p}<0.05$.

relative lactic acid production, respectively (Fig 1c). Among third shuffled library, F3-33 showed highest relative lactic acid production (136\%) compared to that of F2-89 as control $(\mathrm{p}<0.05)$.

The relative growth performance to the control of 180 colonies from third shuffled library (F3) which were picked off randomly. Figure 2 showed 109 and 6 of fusants with growth faster and slower, respectively. The relative growth of F3 fusants library was mostly higher compared with that of the F2-89 fusant as control (Fig 2), while relative lactic acid production of F3 fusants library was mostly lower than that of control (Fig 1c). The best performing lactic acid production of fusants in each round (F1-30, F2-89, F333) were compared for their relative lactic acid production to that of the wild-type (Fig 3). It is shown that F3-33 fusant in the third round genome shuffling performed the highest in lactic acid production.

Shaking Flask Analysis. The performance of F3-33 was further compared with the wild-type strain in shaking flasks (Fig 4a-c). Consistent with smallscale fermentation results, the genome shuffled strain F3-33 produced about a $64.5 \%$ improvement of lactic acid production $\left(12.0 \mathrm{~g} \mathrm{~L}^{-1}\right)$ over the wild-type for $48 \mathrm{~h}$ (Fig 4a). This lactic acid production increased up to $48 \mathrm{~h}$, after which no significant improvement was found. Moreover, the growth characterization and glucose consumption were consistent with the lactic acid production. The fusant F-33 grew 53\% faster compared with the wild-type (Fig 4b), and also consumed glucose faster (Fig 4c).

\section{DISCUSSION}

As lactic acid fermentation at low $\mathrm{pH}$ (at or below the $p K a$ of lactic acid, $\mathrm{pH}$ 3.8) can reduce the cost

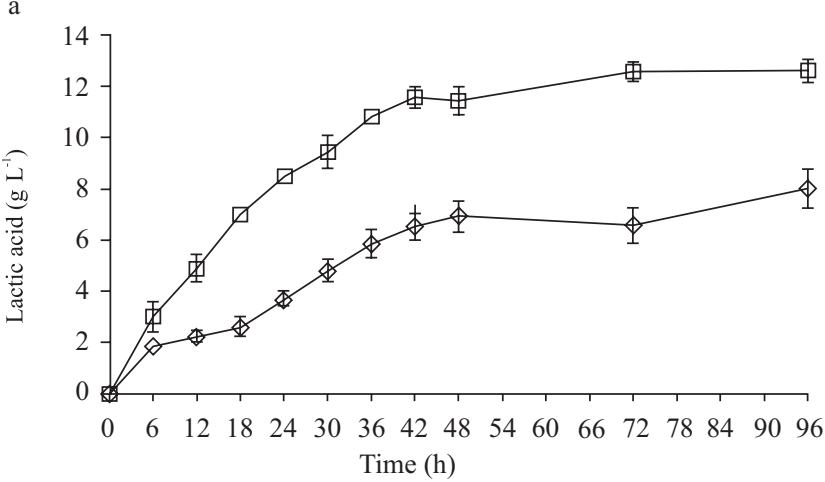

b

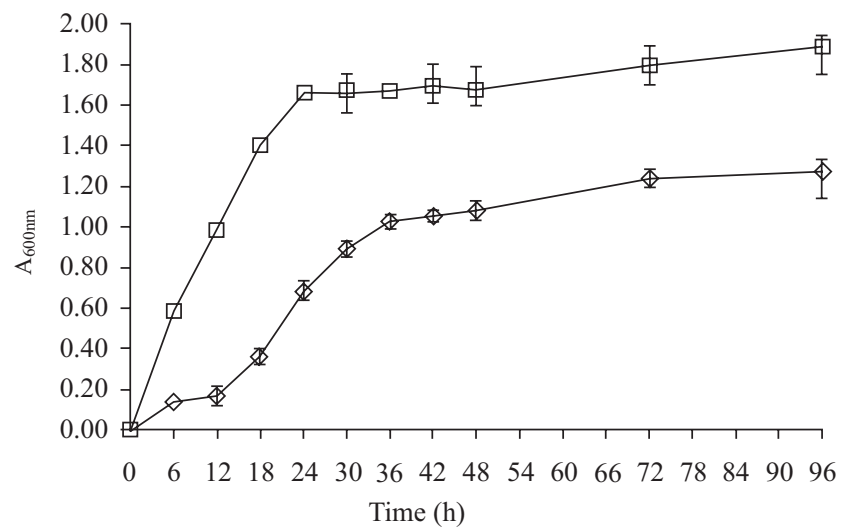

$\mathrm{c}$

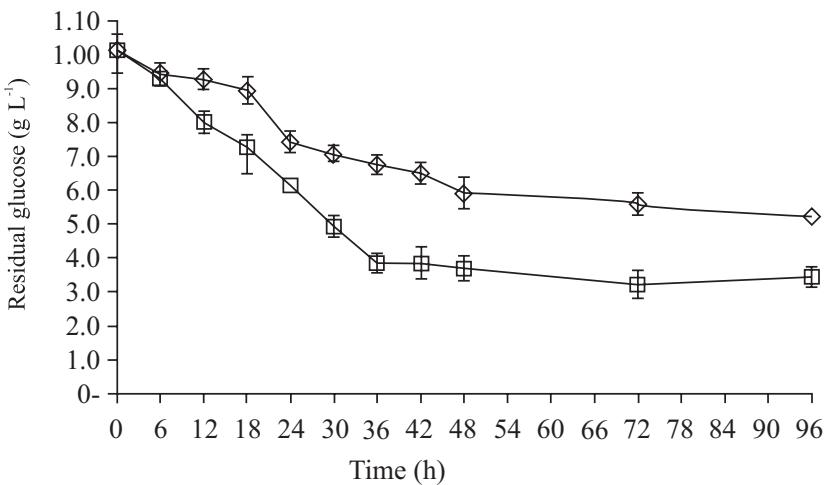

Fig 4 Characterization of lactic acid production: a, cell growth; $b$, and residual sugar (glucose) of fusant F3-33 compared to that of wild type (WT) Lactobacillus plantarum. $\diamond$, WT; $\square$, F3-33.

production and decrease waste, acid tolerance phenotypes meet the performance criteria for industrial strain commercialization. Thus, the strains tolerant to acid conditions are desirable industrial phenotypes (Patnaik et al. 2002). Environmental tolerance of $\mathrm{pH}$ is a complex and yet poorly understood phenomenon, therefore, therefore we applied genome shuffling approach to improve lactic acid production of local L. plantarum. This approach has successfully been used to improve acid tolerance in Lactobacillus through fusion between a low-pH-adapted mutant library population and nitrosoguanidine (NTG) mutant-library-population (Patnaik et al. 2002), and in L. rhamnosus through UV irradiation and NTG mutagenesis (Wang et al. 2007). Here, we used an 
adapted low-pH-mutant library population and an UVirradiation- mutant library population, instead of a nitrosoguanidine (NTG) mutant library population, as the starter of genome shuffling. Since genome shuffling practically mimics the features of natural evolution through recursive genetic recombination, it requires a diverse population of mutants with an improvement of the desired phenotype compared with the wild-type as a starting point (Yu et al. 2008).

The present study showed more than $50 \%$ of fusants with change in their relative lactic acid production and growth. The percentage of fusants with different performing compared to that of their control was increased to $60 \%$ (9\% and $51 \%$ with their lactic acid production and growth, respectively), 66\% (9\% and $57 \%$ with their lactic acid production and growth, respectively) and $85 \%$ (21\% and $64 \%$ with their lactic acid production and growth, respectively) in first, second, and third rounds, respectively. The results of the present study also proved that genome shuffling is an effective strategy for generating strains which become more tolerant to the acid and result in the improvement of lactic acid production. It was shown that the relative lactic acid production of the best performing fusants (F1-30, F2-89, and F3-33) from each of three rounds of genome shuffling were higher than that of the wild-type $(120 \%, 144 \%$, and $167.8 \%$ respectively) (Fig 3), corresponding with the higher growth of those fusants compared with the wild-type (unpublished data). After three rounds of genome shuffling, we obtained F3-33 fusant which had the highest lactic acid production and capable of growing at $\mathrm{pH}$ 4.0. In this regard, F3-33 fusant was further characterized by comparison with the wild-type strain.

In agreement with small-scale fermentation, the lactic acid production of F3-33 fusant was 64.5\% higher compared with the wild-type strain in shaking flasks (Fig 4a). After $48 \mathrm{~h}$ of growth at $\mathrm{pH} 4.0$, the wildtype strain had produced $7.74 \mathrm{~g} \mathrm{~L}^{-1}$ of lactic acid, while the F3-33 fusant produced $12 \mathrm{~g} \mathrm{~L}^{-1}$.

Characterization of F3-33 fusant and the wild-type in the shaking flask showed the lactic acid production was closely correlated with the growth and glucose consumption ( Fig $4 \mathrm{~b}$ and $4 \mathrm{c}$ ). The best performing fusant grew faster, consumed glucose faster, and produced more lactic acid, and also brought the medium to a lower $\mathrm{pH}$ (unpublished data), as reported by Patnaik et al. (2002) and Wang et al. (2007). However, these previously published results showed that the fusants produced three-fold more lactic acid than the wild-type at $\mathrm{pH}$ 4.0. The improvement of lactic acid of our fusant was lower than that of these previous reports. This result may due to the fact that the starting population for each round of fusion had low diversity. The fusant library F1 and F2 were generated from two colonies/ fusants of F0 and F1 fusants library, respectively, while the fusant library F3 was generated from 4 fusants of F3 fusants library. From F1, F2, and F3 fusants library, the percentage of fusants which had changed in their lactic acid production were $9 \%, 9 \%$ and $21 \%$, respectively. These achievements were agreed with the number of fusants used as resources to generate fusants library. Thus, we concluded that the low genetic diversity within a selected population resulted in low recombination and combinatorial library.

These results, however, demonstrated that we had been succeeded in applying the genome shuffling to engineer $L$. plantarum with multiple beneficial improved phenotypes including acid tolerance, lactic acid enhancement, and glucose/substrate consumption at one time. In the future, it is promising that this simple technology is a promising candidate to accelerate poorly characterized strains for commercialization.

\section{ACKNOWLEDGEMENTS}

We would like to thank Yantyati Widyastuti for providing Lactobacillus plantarum BTCC strain. Funding for this project was provided in part by the Indonesian Ministry of Education and Culture Program 2009.

\section{REFERENCES}

Carlson TL, Peters EM, inventors; Cargill, Inc (Wayzata, MN), assignee. 2002. Low $\mathrm{pH}$ lactic acid fermentation. United State patent US $6,475,759$

Cocconcelli PS, Morelli L, Vescobo M, Bottazzi V. 1986. Intergeneric protoplast fusion in lactic acid bacteria. FEMS Microbiol Lett. 35 (2-3):211-214. doi: 10.1111/j.1574-6968.1986.tb01529.x.

Dai MH, Copley SD. 2004. Genome shuffling improves degradation of the anthropogenic pesticide pentachlorophenol by Sphingobium chlorophenolicum ATCC 39723. Appl Environ Microbiol. 70(4):2391 2397. doi: 10.1128/AEM.70.4.2391-2397.2004.

Dubois M, Gilles KA, Hamilton JK, Rebers PA, Smith F. 1956. Colorimeteric method for determination of sugars and related substances. Anal Chem. 28(3):350-356. doi: 10.1021/ac60111a017.

Hida H, Yamada T, Yamada Y. 2007. Genome shuffling of Streptomyces sp. U121 for improved production of hydroxycitric acid. Appl Microbiol Biotechnol. 73(6):1387-1393. doi: 10.1007/s00253-006-0613-1.

John RP, Anisha GS, Nampoothiri KM, Pandey A. 2009. Direct lactic acid fermentation: Focus on simultaneous saccharification and lactic acid production. Biotech Adv. 27(2):145-152. doi: 10.1016/j.biotechadv. 2008.10.004.

Patnaik R, Louie S, Gavrilovic V, Perry K, Stemmer WPC, Ryan CM, del Cardayré S. 2002. Genome shuffling of Lactobacillus for improved acid tolerance. NatBiotechnol. 20(7):707-712. doi: 10.1038/nbt0702-707.

Porro D, Bianchi MM, Brambilla L, Menghini R, Bolzani D, Carrera V, Lievense J, Liu CL, Ranzi BM, Frontali L, Alberghina L. 1999. Replacement of a metabolic pathway for large-scale production of lactic acid from engineered yeasts. Appl Environ Microbiol. 65(9):4211-4215. 
Singh SK, Ahmed SU, Pandey A. 2006. Metabolic engineering approaches for lactic acid production. Process Biochem. 41(5):991-100. doi: 10.1016/j.procbio.2005.12.004.

Stephanopoulos G. 2002. Metabolic engineering by genome shuffling. Nat. Biotechnol. 20(7): 666-668. doi: 10.1038/nbt0702-666.

Wang Y, Li Y, Pei X, Yu L, Feng Y. 2007. Genome-shuffling improved acid tolerance and L-lactic acid volumetric productivity in Lactobacillus rhamnosus.JBiotechnol. 129(3):510-515.doi: 10.1016/j.jbiotec.2007.01.011.
Yu L, Pei X, Lei T, Wang Y, Feng Y. 2008. Genome shuffling enhanced Llactic acid production by improving glucose tolerance of Lactobacillus rhamnosus. J Biotechnol. 134(1-2):154-159. doi: 10.1016/j.jbiotec. 2008.01.008.

Zhang DX, Perry K, Vinci VA, Powell K, StemMer WPC, Cardayre SD. 2002. Genome shuffling leads to rapid phenotype improvement in bacteria. Nature. 415(6872): 644-646. doi: 10.1038/ 415644a. 